\title{
Prototype of The Quran and Translation of The Ministry of Religion 2019 Edition in Quran Live Chat on Whatsapp and Telegram Applications
}

\author{
Fakhri Putra Tanoto \\ Department of Al-Qur'an and Tafsir, Faculty of Usuluddin \\ Sunan Gunung Djati State Islamic University \\ 1171030068@student.uinsgd.ac.id
}

\begin{abstract}
This study aims to integrate the Qur'an and its translation in an instant messaging application. The method used This research uses a mixed method, which combines qualitative and quantitative methods. This study resulted in a product in the form of a chatbot named Quran Live Chat and concluded that there were benefits felt by users in searching for the latest verses and translations belonging to the Ministry of Religion for the 2019 edition of the refinement by using instant messaging applications such as Whatsapp and Telegram. This study recommends that further research be carried out related to the integration of the book of interpretation.
\end{abstract}

Keywords: Al-Qur'an, Chatbot, Telegram, Whatsapp.

\section{Introduction}

In today's digital era who does not want to make all activities feel easier, one of them when looking for a verse in the Qur'an certainly wants to be done in a practical way. Interactive Qur'an is a means of understanding the science of the Qur'an easily (Hambali \&Surjono, 2015). Nowadays technology has helped many people in various ways, one of them is in learning. Chatbot technology contained in instant messaging applications is one of the perceived benefits in the ease of interacting (Aulia et al., 2019). Efforts to integrate the Qur'an with chatbot technology can make people in studyingthe Qur'an should interact through instant messaging applications.

Hootsuite in 2019 conducted research on users of instant messaging applications and as a result many Indonesians who use Whatsapp and Telegram applications by $83 \%$ means as many as $124,000,000$ Indonesians (Jayani, 2019). There is a similar research with the title "Utilization of Instant Messaging For Learning Applications Reading the Qur' an With Tsaqifa Method." This article concludes that the use of chatbots that have been created can be a learning tool and more interactive for users (Aulia et al., 2019). In 
addition, another study with the title "Utilization of Whatsapp Application In Learning Media At UIN Ar-Raniry Banda Aceh. " This article concludes that the effectiveness of the use of Whatsapp application in learning that became one of the characteristics of the web technology generation 2.0 (Prajana, 2017).

The results of previous studies are useful for researchers inm enyusun frame of mind. There has been a lot of research that utilizes chatbot technology as a means of education. However, until now no one has researched and made the product of the Qur'an chatbot. Therefore, researchers focused this discussion on the systematics of making chatbots of the Qur'an that eventually produce a product with the aim of benefiting the people of Indonesia and helping disseminate the Qur'an and translation of the Ministry of Religious Affairs improvement edition 2019. All discussions and products in this study are the original results of researchers so that they can be accounted for. The question in this study is how is the Qur'an interactively present in instant messaging applications and provide benefits to Indonesians in the digital age?

\section{Research methods}

This study uses a mixed method, which combines qualitative and quantitative methods (Masrizal, 2011). Qualitative method through literature study (Darmalaksana, 2020a) and quantitative methods with experiments on product testing (Jaedun, 2011). Library sources are collected both primary and secondary (Darmalaksana, 2020b). The main sources for making this product are the Al-Qur'an and the translation of the Ministry of Religion for the 2019 edition of the completion of Lajnah Pentashihan Mushaf Al-Qur'an (LPMQ). As for the interpretation in carrying out the analysis used translation, systems approach, and technology tools.

\section{Results and Discussion}

Chatbot is software that can communicate with humans using natural language (Zuraiyah et al., 2019). The conversation model uses artificial intelligence to be able to understand the user's speech and provide responses that are relevant to the problem discussed by the user. Chatbots can also be interpreted as algorithms and programming to respond or interact with users via text or voice messages (Albayrak et al., 2018). The response given by the chatbot depends on the input keyword that was started. The chatbot will reply to keywords with the most similar pattern from the textual database (Oktavia, 2019). 
Figure 1. Illustration of how a chatbot works

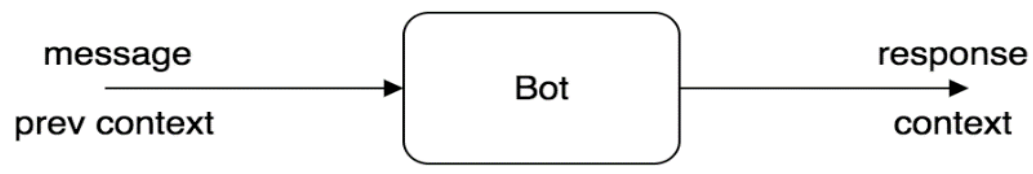

Figure 1. Illustration of how a chatbot works when it gets messages based on words, and will respond to messages sent according to the messages that have been specified.

Researchers use several supporting applications in making the chatAl-Qur'an chatbot, as follows:

Table 2. Applications for creating chatbots

\begin{tabular}{|c|l|l|}
\hline \multicolumn{2}{|c|}{ Chatbot Creation App } \\
\hline No & \multicolumn{1}{|c|}{ App } & \multicolumn{1}{c|}{ Functions/Usage } \\
\hline 1. & Microsoft Word $($ docx $)$ & Processing verses and translations \\
\hline 2. & Microsoft Excel $(c s v)$ & Processing database \\
\hline 3. & Google Spreadsheet & Save message data \\
\hline 4. & BlueStacks App Player & Virtual machine (emulator) \\
\hline 5. & WhatsAuto & Activate chatbot database \\
\hline
\end{tabular}

Table 2. Applications used to create chatbots

Figure 3. Chatbot on Google Sheets

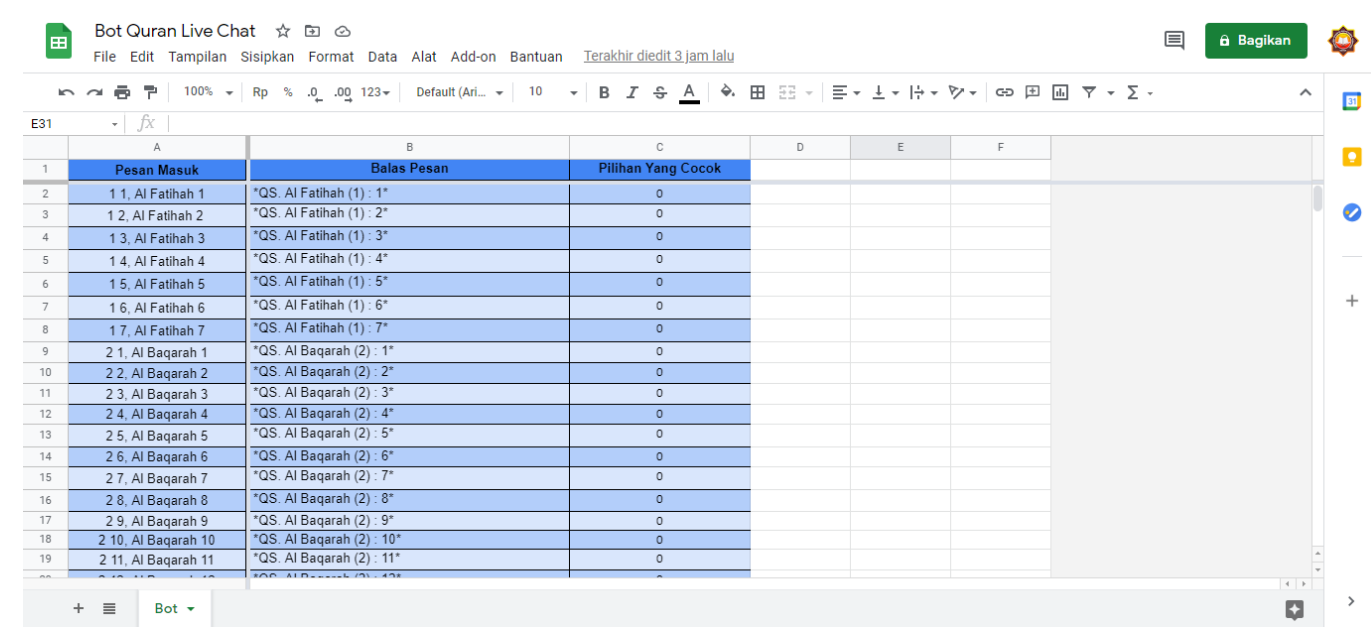

Figure 3. Chatbot of incoming messages and replying to messages on Google Sheets

Quran Live Chat can be contacted $1 \times 24$ hours according to user needs. Currently, you can display verses and translate them by calling the 
number 0851-5502-4733 through the Whatsapp and Telegram applications. In today's modern era, there are always new innovations in developing the interpretation of the Qur'an. This aims to provide convenience to Muslims in studying, exploring, and embellishing the contents of the Qur'an in each verse (Faizah \& Rusydati, 2021). The presence of Quran Live Chat can be a problem solving for Indonesian people who always use smartphones every day but rarely hold the Qur'an.

Figure 4. Chatbot trial

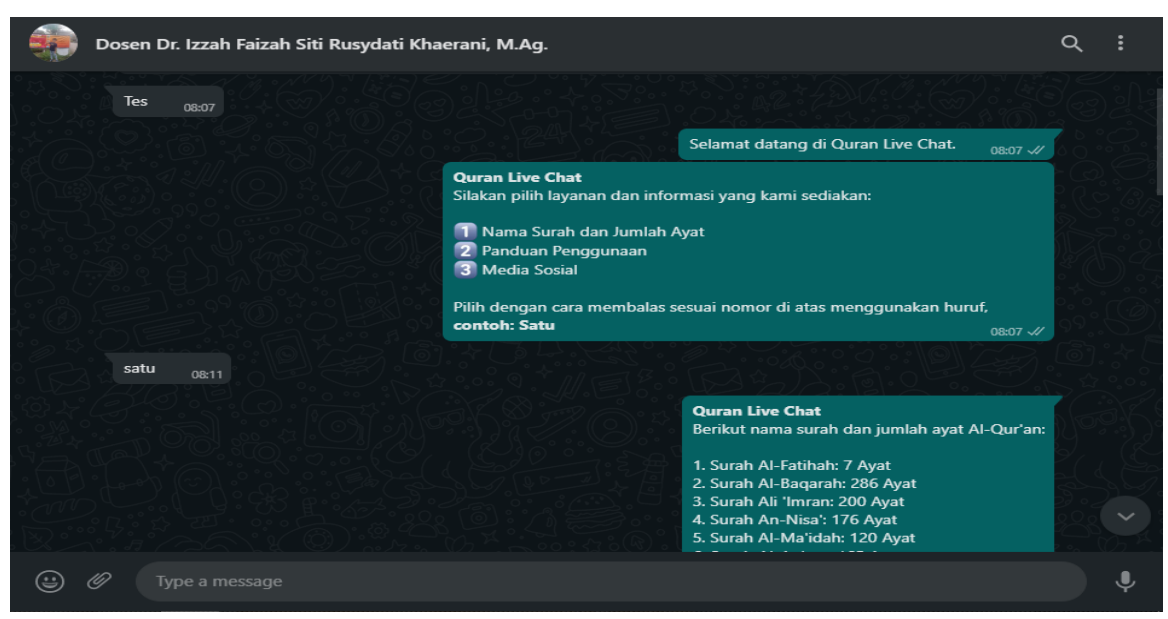

Figure 4. Testing the chatbot (Quran Live Chat)

Quran Live Chat has a website with the domain address www.quranlivechat.com as a means of information that can be used by its users. Users can see the latest info on feature updates, usage tutorials, find out common questions and can follow the Quran Live Chat social media because everything is well integrated.

Figure 5. Quran Live Chat Website

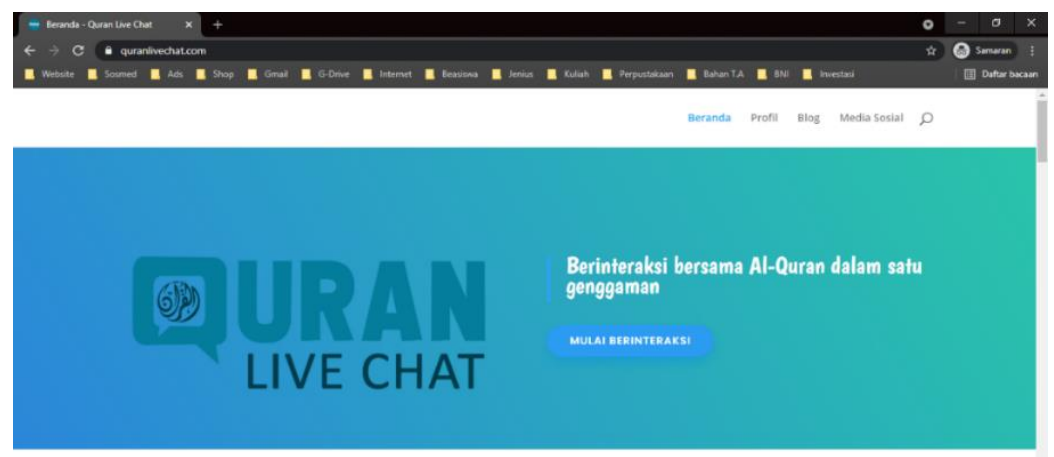


The results of this study support the results of previous studies that the use of chatbots can be a more interactive learning tool for users (Aulia et al., 2019). This product is also a Whatsapp application development in learning as a characteristic of the generation of web 2.0 technology (Prajana, 2017). This original product is expected to be an educative alternative to instant messaging, where Whatsapp and Telegram are used by 124,000,000 Indonesians (Jayani, 2019).

\section{Conclusion}

The integration of the Qur'an and the translation of the 2019 edition of the Ministry of Religion with the instant messaging application has been completed. The results of this integration are now present in the Qur'an chatbot on the Whatsapp and Telegram applications, which are named Quran Live Chat. Through this Quran Live Chat, the Indonesian people can find out the verses and translations of the latest edition of the Ministry of Religion in the grip of a smartphone and reviewers of the Qur'an and interpretation can make it easier to study or research with the help of technology. This research has shortcomings and it is hoped that further research can be carried out as well as the development of new features in Quran Live Chat such as the Qur'an index, interpretation, and chatbot support on other instant messaging applications. So this study recommends further on this matter.

\section{References}

Albayrak, N., Ozdemir, A., \& Zeydan, E. (2018). An overview of artificial intelligence based chatbots and an example chatbot application. 26th IEEE Signal Processing and Communications Applications Conference, SIU 2018, August, 1-4. https:/ / doi.org/10.1109/SIU.2018.8404430

Aulia, F. M., Sudarma, M., \& Suyadnya, I. M. A. (2019). Pemanfaatan Instant Messaging Untuk Aplikasi Pembelajaran Membaca Al-Qur'an Dengan Metode Tsaqifa. SINTECH (Science and Information Technology) Journal, 2(1), 24-32. https:/ / doi.org/10.31598/ sintechjournal.v2i1.301

Darmalaksana, W. (2020a). Cara Menulis Proposal Penelitian. Fakultas Ushuluddin UIN Sunan Gunung Djati Bandung, 31.

Darmalaksana, W. (2020b). Metode Penelitian Kualitatif Studi Pustaka dan Studi Lapangan. Pre-Print Digital Library UIN Sunan Gunung Djati Bandung, 1-6. http:/ / digilib.uinsgd.ac.id/32855/1/Metode Penelitian Kualitatif.pdf

Faizah, I., \& Rusydati, S. (2021). Digitizing Website-Based Qur' anic Tafseer Digitaslisasi Tafsir Al-Qur' an Berbasis Website. 4, 188-201.

Hambali, H., \& Surjono, H. D. (2015). Pengembangan Multimedia Pembelajaran Interaktif Untuk Belajar Membaca Al-Quran Metode Qira' Ati Di Tpq Raudlotut Thalibin. Jurnal Inovasi Teknologi 
Pendidikan, 2(1), 74-82. https://doi.org/10.21831/tp.v2i1.5205 Jaedun, A. (2011). Metodologi Penelitian Eksperimen. Puslid Dikdasmen, 012.

Jayani, D. H. (2019). Akses Dibatasi, Berapa Pengguna WhatsApp di Indonesia? Databoks.

https:/ / databoks.katadata.co.id/datapublish/2019/05/23/aksesdibatasi-berapa-pengguna-whatsapp-di-indonesia

Masrizal. (2011). Mixed Method Research Masrizal. Kesehatan Masyarakat Andalas, 6(1), 53-56.

Oktavia, C. A. (2019). Implementasi Chatbot Menggunakan Dialogflow dan Messenger Untuk Layanan Customer Service. 4(3), 36-40.

Prajana, A. (2017). Pemanfaatan Aplikasi Whatsapp Untuk Media Pembelajaran Dalam Lingkungan Uin Ar-Raniry Banda Aceh. Cyberspace: Jurnal Pendidikan Teknologi Informasi, 1(2), 122. https:/ / doi.org/10.22373/cs.v1i2.1980

Zuraiyah, T. A., Utami, D. K., \& Herlambang, D. (2019). Implementasi Chatbot Pada Pendaftaran Mahasiswa Baru Menggunakan Recurrent Neural Network. Jurnal Ilmiah Teknologi Dan Rekayasa, 24, 91-101. 